University of Rhode Island

DigitalCommons@URI

The Rhode Island Current Conditions Index

Economics

8-2019

\title{
Rhode Island Current Conditions Index - August 2019
}

Leonard Lardaro

University of Rhode Island, lardaro@uri.edu

Follow this and additional works at: https://digitalcommons.uri.edu/ricci

Part of the Econometrics Commons

Terms of Use

All rights reserved under copyright.

\section{Recommended Citation}

Lardaro, Leonard, "Rhode Island Current Conditions Index -- August 2019" (2019). The Rhode Island Current Conditions Index. Paper 189.

https://digitalcommons.uri.edu/ricci/189

This Newsletter is brought to you for free and open access by the Economics at DigitalCommons@URI. It has been accepted for inclusion in The Rhode Island Current Conditions Index by an authorized administrator of DigitalCommons@URI.For more information, please contact digitalcommons-group@uri.edu. 


\title{
CURRENT CONDITIONS
}

\section{LEONARD LARDARO, URI}

\author{
Available Online: http: / www.Ilardaro.com/current.htm \\ Twitter: @ladardo
}

VOL XXVI

NUMBER 9

AUG 2019

After a two-month uptick in the pace of economic activity, Rhode Island's economy slowed a bit in August. What is notable is that several of economic indicators that recently moved past their prior lulls managed to sustain their newly found momentum while others, like Retail Sales, continued to perform extremely well.

While our negatives gained a bit on our positives this month, causing the Current Conditions Index to fall from its July value of 83 down to 67 , actual indicator performances were not as weak as focusing merely on the CCI's value might suggest. In August, eight of the twelve indicators contained in the CCI improved, with several strong and encouraging performances. The indicators that failed to improve, however, displayed substantial weakness. Not only did the CCI fail to exceed its year-earlier value, after doing so in July for the first time since May of 2018, only two of the five leading indicators contained in the CCI improved.

So, at this point, Rhode Island's economy might well find itself at an inflection point. Will we sustain the uptick in momentum of the last three months or will we revert back to diminished momentum of the past several years? The answer for Rhode Island lies almost entirely with how well the national and Massachusetts economies perform in the upcoming months. Sadly, Rhode Island's continuing failure to meaningfully reinvent itself as a post-manufacturing economy (since late 1987), aside from the highly publicized deals that often don't materialize, has

\begin{tabular}{|l|r|r|}
\hline \multicolumn{3}{|c|}{ CCI Indicators - \% Change } \\
\hline Government Employment & 1.5 & Y \\
\hline US Consumer Sentiment & -4.4 & \\
\hline Single-Unit Permits & -9.0 & \\
\hline Retail Sales & $\mathbf{8 . 3}$ & Y \\
\hline Employment Services Jobs & 3.5 & Y \\
\hline Priv. Serv-Prod Employment & 2.4 & Y \\
\hline Total Manufacturing Hours & -10.4 & \\
\hline Manufacturing Wage & 2.4 & Y \\
\hline Labor Force & $-\mathbf{0 . 2}$ & \\
\hline Benefit Exhaustions & $-\mathbf{2 . 0}$ & Y \\
\hline New Claims & -19.0 & Y \\
\hline Unemployment Rate (change) & $-\mathbf{0 . 3}$ & Y \\
\hline \multicolumn{2}{|c|}{ Y = Improved Value } \\
\hline
\end{tabular}

left our economy largely "adrift" in the current economic environment, hoping for a substantial uptick in economic activity while remaining saddled with the reality of having to deal with the consequences of FILO should the national economy slow further. Taken together, all of this is a sad illustration of an ongoing series of self-inflicted wounds. Does our state's economy remain in second gear, or will we downshift back to first gear? Stay tuned, and remain focused on how well the US and Massachusetts economies fare.

There were several notable positives in August. Both the monthly employment and labor force participation rates improved again,

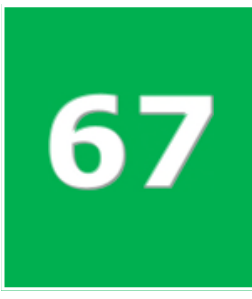

\begin{tabular}{|c|c|c|} 
& Jan & Feb \\
\hline 2018 & 75 & $100 \uparrow$ \\
\hline 2019 & 75 & $33 \downarrow$ \\
\hline
\end{tabular}

\begin{tabular}{|c|c|}
\hline Mar & Apr \\
\hline $83 \uparrow$ & $83 \uparrow$ \\
\hline $58 \uparrow$ & 58 \\
\hline
\end{tabular}

Copyright @ 2018, 2019 Leonard Lardaro, Ph.D. All rights reserved. 